\title{
Perspectives
}

\section{Sexism in the English Language}

\section{Margaret Piercey}

Sexism and the ESL Teacher: Restarting the Discussion

In our patriarchal society there is still evidence of inherent sexism in every aspect of life. This perspective essay concentrates on the sexism that is inherent in the English language. Although this ongoing debate may be considered by some as outdated, I disagree. In writing this essay I attempt to bring to the forefront an important issue and, I hope, to restart discussions. I do not assume the authority of summing up the whole debate, but rather would like to reintroduce ESL teachers to the subject and to sensitize them to covert assumptions and overt practices that seem to sustain sexism.

As teachers and professionals we have the responsibility to continue learning and growing, to search for, develop, and offer our students our best teaching practices. We need to assess not only our students, but ourselves as well. Through observations of, and reflections on, our own teaching procedures, we may want to redefine our goals and practices to include nonsexist material, language, and literature. Numerous publications that deal with sexism and nonsexist teaching are available from departments of education and teachers' associations.

To draw a connection between the work we do as ESL teachers and the problems women face in our society today can be a daunting task. Questioning some of our views and values requires strength. However, it is an important aspect of our work as ESL teachers if we wish to give all our students the necessary tools to be whole, competent, and dynamic members of society. In her book Feminism and Linguistic Theory Cameron (1992) points out that there is

a good deal of feminist work emphasizing the importance of cultural representation of gender-men and women as they appear (or in the case of women don't appear) in stories, pictures, textbooks, scholarly articles, and so on-in forming the identities of real women and men, their notions of masculinity and femininity, their expectations of what is possible and their ideas of what is normal. (p. 5)

I structure this essay around three themes: English as a part of culture, the discrimination in English, and the marginalization of women in literature. All of this has a profound effect on women in society and girls in schools. It is important for ESL teachers to be conscious of sexism in English (as this is 
the language we teach), to stop contributing to it, and in turn to use and support nonsexist language.

\section{English as a Dominant Language: A Man-Made Language}

In his book Linguistic Imperialism Phillipson (1992) suggests that the acquisition of English as a second language has been correlated, and is related, to "nationalism, nationism, development, modernity, efficiency, western civilization, and many other culturally-loaded values, all of which are features of contemporary capitalism" (p. 85). This creates the inevitability that individuals who learn English as a second language will also learn the cultural and sociological ideologies inherent in this language.

According to Phillipson, teaching English has three functions:

First, part of the widespread legitimation for English is to qualify people to build up the nation... It therefore has an economic-reproductive function... Secondly, English is also supposed to bring 'modern' ideas with it, to be a channel for interpersonal, social, and cultural values. It therefore has an ideological function.... Thirdly, English has a repressive function, in that there is no choice other than to use the language in English classes. (pp. 68-69)

As ESL teachers it is up to us to be aware of all these functions. Our students are not only learning a language as a tool to communicate with others, but they are also learning the cultural values that are embodied in the language.

In Man Made Language Spender (1980) concludes that "women could learn to speak exactly like men and yet still be evaluated as less successful-even hesitant and tentative-precisely because it is not only the language which determines the evaluation, but the sex" (p. 79). Because women's speech is not considered assertive, it is often assumed that they are lacking something. However, we must be aware that this does not mean that women do not speak well, it just means that they do not speak like men. ESL teachers need to be sensitive to this when we evaluate students' learning and progress.

Spender (1980) goes even further to suggest that language actually constructs our reality. We constant use symbols to make sense of the world in which we live, and language is a set of symbols, with inherent limitations, that we use to determine our reality.

In this context it is nothing short of ludicrous to conceive of human beings as capable of grasping things as they really are, of being impartial recorders of the world. For they themselves, or some of them, at least, have created or constructed that world as they have reflected themselves within it. (p. 139)

She concludes that this is a language trap in which we are caught. We do not want to organize our world any other way; moreover, "it has been the 
dominant group - in this case, males-who have created the world, invented the categories, constructed sexism and its justification and developed a language trap which is in their interest" (p. 142).

The English language is man-made, and it enshrines ancient biases and prejudices against women. Men are the influential force in shaping our world by having the power to create the symbols. The English language as a set of symbols "represents man's image of himself and of ourselves and the world as his creation" (Kramarae \& Treichler, 1985, p. 225). Thus language serves men and is only a tool that women have borrowed to be able to communicate with them, the dominant group.

\section{Women's Exclusion from Language: Sexism and Sexist Language}

A young man and his father are in an auto accident; the father is killed and the young man is rushed to the hospital. The surgeon, upon entering the room and seeing the patient, exclaims, "Oh my God, I can't operate; it's my son!" How is this to be explained? (p. 436)

The answer is, of course, that the surgeon is the young man's mother. This riddle works because the listeners' conception of the word surgeon does not include the possibility of a woman.

Sexism, by definition, is a social relationship in which males have authority and power over females. This relationship includes "behavior, policy, language or other action of men or women which expresses the institutionalized, systematic, comprehensive or consistent view that women are inferior" (p. 411).

In The Feminist Critique of Language Cameron (1990) suggests that language

could be seen as a reflection of sexist culture; or ... it could be seen as a carrier of ideas and assumptions which become, through their constant re-enactment in discourse, so familiar and conventional we miss their significance.... Thus sexism is not merely reflected but acted out and thus reinforced in a thousand banal encounters. (p. 14)

Stanley (Kramarae \& Treichler, 1985) defines sexist language as "one of the most powerful means of perpetrating masculinist interpretations of the world, including the view that wimin are inferior, passive, and, by definition, subordinate to males" (p. 412). Stanley also found that "many of the words for women had sexual overtones and despite ... the smaller sample (usually) assigned to women there were 220 words for a sexually promiscuous female and only 20 for a sexually promiscuous male" (Cameron, 1992, p. 84). For years men in courts and governments debated whether women should be included in the term person, for example, the Persons Case of 1928 (Cruickshank, 1988). The English language is sexist because it is constructed with a 
bias that always favors males. In English semantics, or in the meanings available in English, males not only have more words but they have more positive words. There is "the existence of a semantic rule which determines that any symbol which is associated with the female must assume negative (and frequently sexual-which is also significant) connotations" (Spender, 1980, p. 19). Simone de Beauvoir argued in her book The Second Sex that "all the negative characteristics of humanity as men perceive them are projected onto women" (Cameron, 1992, p. 84).

When talking about gender in the English language, one must look at the masculine-feminine dichotomy that arises in the vocabulary. Gender is determined by meaning, not form; therefore, in seemingly neutral terms a sex is assigned. Consider gender in the following adjectives: aggressive, arrogant, charming, confident, dependant, emotional, flirtatious, gentle, logical, nagging, rational, stable, submissive, talkative, and tough. Cameron (1992) suggests that "the attribution of gender is relational: it depends on the contrast between two terms" (p. 83). Therefore, we need to consider gender connotations if we choose to include opposites in our lesson planning such as tough-weak and active-passive, because a lesser value is placed on the feminine as it is opposed to the masculine. Names such as Sir-Madam and bachelor-spinster that do denote male and female in their definitions are clear examples of the feminine taking negative or inferior connotations. "Gender seems to be a conceptual component in many unrelated lexical items; and that oppositions often function covertly as hierarchies, which means it may not be a neutral fact that this system represents women as the negative of men" (p. 87).

Sexist language "cannot be regarded simply as the 'naming' of the world from one, masculinist perspective; it is better conceptualized as a multifaceted phenomenon occurring in a number of quite complex systems of representation, all with their places in historical traditions" (Cameron, 1990, p. 14). Because the English language is man-made, it reflects the cultural values of men, what they find important (and what they do not), and these values are then handed down to each new generation.

Through the use of sexist language women are effectively eliminated and excluded from the day-to-day reality that they exist. Words such as he and man are supposedly employed to include women. However, they are clear examples of a sexist linguistic structure because what they are effectively doing is excluding women, as women could never experience nor identify with he. Margrit Eichler, in Women and Men: Interdisciplinary Readings on Gender (Nemiroff, 1987), concludes that "the use of male terms for generic purposes constitutes a sexist practice that has two major flaws: for one, the male terms are not experienced as truly generic. For the other, to use terms that have two quite different meanings is highly confused and confusing" ( $p$. 28). 
Male grammarians have handed down "Rule Number 21," which is the use of he and man as generic as a means of arguing for the superiority of males in the structure of the language because "the male gender was more comprehensive than the female" (Spender, 1980, p. 148). This opinion, which is based on no sound facts, has been used "to formulate a grammatical rule which would put the users of the language in the 'wrong' if they did not adhere to this belief" (p. 148). However, to use the alternative they in the singular as, for example, in the phrase "Anyone can play if they learn" has been determined to be quite common even though it is considered grammatically incorrect. As ESL teachers we need to be open to alternatives, to use them in our own teaching practices, and to relax rigid adherence to this rule in the name of grammatical correctness.

\section{Women's Marginalization in Literature: Sex Objects and Beauties}

In literature, which is the written form of language, women are marginalized and relegated to positions to satisfy male fantasies. Women's real experiences are hidden and obscured behind a language that insists on their passivity and silence.

In many children's stories that are used to teach values, boys and girls receive two different messages. Boys, who will become men, learn that they are the doers, "that a great man risks all for intellectual daring, for progress and for the public good" (Wolf, 1991, p. 61), whereas young girls, who will become women, learn that they have things done to them and for them and that their importance lies in how they look. Take, for example, the popular fairytale Sleeping Beauty. The beautiful princess is asleep, and the only thing that will wake her up is a kiss from the handsome prince. So she lies there waiting for him, looking beautiful, and is eventually saved by him.

As a young girl grows up she realizes that not only must she look beautiful, but she must be sexy and desirable as well. And if she reads anything like Henry Miller's Sexus, she will learn that sexual intercourse is not about love, but about domination and the fulfillment of men's wants and needs, not her own. Kate Millett explores this concept in her book Sexual Politics (Abrams, 1988). She analyzes selected passages from D.H. Lawrence, Henry Miller, and Norman Mailer "revealing the ways in which the authors, in fictional fantasy, exploit sexuality in order to aggrandize their aggressive phallic selves or to master and degrade women as submissive sexual objects" (p. 208).

\section{Women's Herstory: ESL Students Need the Whole Story}

Adrienne Rich has said that women's "enforced ignorance has been a crucial key to their powerlessness" (Backhouse \& Flaherty, 1992, p. 149). Women are ignorant of their past because their past stories have never had any importance for men. In the education system women learn men's history: they read 
the books written by men, they study the theories of their forefathers. Thus women's knowledge of men is vast; however, knowledge of themselves is limited. Spender (1980) suggests that this silence has been man-made.

It is not that women have not written, nor that they have not broken through some of the restrictions and been heard: it is that their contributions have been suppressed through a variety of social institutions which men have created and controlled. (p. 205)

We must know where we have been in order to know where we are going. Thus teachers of English as a second language play an important role. We must tell the whole story. It is up to us to teach women's herstory, as well as men's history, to give girls and women a chance to become self-confident, self-defining individuals. We must be aware that sexism is prevalent in the English language, and when teaching it we must use terms that include women such as police officer instead of policeman. We must use the pronoun she even if it seems inconvenient. We must specifically look for and use literary examples of women seen in a positive light: materials that portray women as active participants in their own destinations. When having guest speakers in our classrooms, we must ensure that both women and men are equally represented. English is not neutral-it perpetrates the ideology of a patriarchal culture. If we want to eliminate the idea that women are inferior to men, we must start by using nonsexist language, teaching nonsexist literature, and studying herstory.

\section{The Author}

Margaret Piercey completed her BA at Memorial University of Newfoundland in sociology and women's studies. She completed her BEd at the University of Québec at Chicoutimi in teaching English as a second language. Ms. Piercey is currently the President of TESL Newfoundland/Labrador. She is a substitute teacher with the Avalon East School Board and an educational consultant for the firm Language Plus in St. John's.

\section{References}

Abrams, M.H. (1988). A glossary of literary terms (5th ed.). Orlando, FL: Harcourt Brace Jovanovich.

Backhouse, C., \& Flaherty, D.H. (1992). Challenging times: Women's movements in Canada and the United States. Montreal, QC: McGill-Queen's University Press.

Cameron, D. (1990). The feminist critique of language. New York: Routledge, Chapman, and Hall.

Cameron, D. (1992). Feminism and linguistic theory. New York: St. Martin's Press.

Cruickshank, D.A. (1988). The persons case. Canadian Encyclopedia (vol. 3, p. 1645). Edmonton, $A B:$ Hurtig.

Kramarae, C., \& Treichler, P. A. (1985). A feminist dictionary. London: Pandora Press.

Nemiroff, G.H. (1987). Women and men: Interdisciplinary readings on gender. Montreal, QC: Fitzhenry \& Whiteside.

Phillipson, R. (1992). Linguistic imperialism. Oxford: Oxford University Press. Spender, D. (1980). Man made language. London: Routledge and Kegan Paul. Wolf, N. (1991). The beauty myth. Toronto, ON: Vintage Books. 